belang het gebruik van de richtlijn te bevorderen. Implementatiestrategieen moeten zich daarbij richten op het wegnemen van barrières en versterken van bevorderende factoren.
1 Universiteit Twente; 2 GGD Twente Informatie:a.a.j.konijnendijk@ utwente.nl

\section{JGZ-richtlijn Voeding en eetgedrag}

\section{C.I. Lanting, N. Heerdink en} J.P. van Wouwe ${ }^{1}$

\section{Achtergrond en doelstelling} Ouders maken zich vaak zorgen over de voeding en het eetgedrag van hun kind: krijgt het kind voldoende gezonde voeding, hoe om te gaan met eetpatroon en -gedrag en krijgt het kind geen tekorten die gevolgen voor de groei en ontwikkeling kunnen hebben? In opdracht van ZonMw zijn 2 op elkaar aansluitende evidence-based richtlijnen ontwikkeld: een richtlijn Voeding en Eetgedrag voor de jeugdgezondheidszorg (JGZ), vooral gericht op gezonde voeding en begeleiding van ouders, en een richtlijn voor de Nederlandse Vereniging voor Kindergeneeskunde (NVK) Signalering van somatische oorzaken van afwijkend voedingsgedrag bij kinderen, die is gericht op diagnosticering. Er is zorg gedragen voor unifor- me criteria voor verwijzing en advisering. De criteria voor het verwijzen van kinderen met een ernstig eetprobleem of een eetstoornis naar de GGZ is afgestemd op de kinderen jeugdpsychiatrie.

\section{Methode}

De uitgangsvragen voor het systematisch literatuuronderzoek naar bewijs ten behoeve van de evidencebased JGZ-richtlijn Voeding en eetgedrag zijn geformuleerd door een multidisciplinaire werkgroep. Bij ontbreken van bewijs is uitgegaan van consensus en best-practice. In de richtlijn is ook het commentaar verwerkt uit een proefimplementatie en een landelijke commentaarronde.

\section{Resultaten}

Kinderartsen stellen 'alarmsymptomen' op als criteria voor verwijzen, onder andere: onvoldoende groei, symptomatologie van mond en keel, neus en oor, en neurologische symptomen. Kinder- en jeugdpsychiaters formuleren de symptomen die erop wijzen dat waarschijnlijk sprake is van gestoord eetgedrag, bijvoorbeeld voedselweigering langer dan een maand en het ontstaan van de problemen voor het tweede levensjaar. De belangrijkste aandachtspunten voor de JGZ zijn: 1) richtlijnen voor gezonde voeding en een evenwichtig dieet in overeenstemming met de richtlijnen van de Gezondheidsraad; 2) geleidelijke introductie vanaf de vierde levensmaand van vast voedsel bij borstvoeding of kunstvoeding; 3 ) een regelmatig eetpatroon van niet meer dan 7 eet- en/of drinkmomenten per dag; 4) advisering voor ouders van kinderen in diverse leeftijden over eetgedrag en eetpatroon, en over het omgaan met lichte eetproblemen; 5) volgens de afgesproken criteria verwijzen naar kinderarts, kinderpsycholoog of kinderpsychiater. 1 TNO, Leiden

Informatie: caren.lanting@tno.nl
Een evidence-based aanpak van koorts bij kinderen jonger dan 3 jaar in de preventieve gezinsondersteuning en kinderopvang in Vlaanderen

\section{Laureyns en N. De Ronne ${ }^{1}$}

\section{Achtergrond en doelstelling} Koorts bij kinderen jonger dan 3 jaar is een symptoom gedefinieerd als stijging van de lichaamstemperatuur boven of gelijk aan $38^{\circ} \mathrm{C}$. Dit is een normale fysiologische respons op het binnenkomen van infectieuze agentia, waarbij exogeen en endogeen aangemaakte pyrogenen de in de hypothalamus gereguleerde lichaamstemperatuur op een hoger punt zetten. Deze respons is een belangrijk immunologisch verdedigingsmechanisme. Koorts wordt meestal veroorzaakt door een benigne virale infectie, maar het kan een teken zijn van een ernstig verlopende infectie, zoals meningitis, sepsis, pneumonie, enz. Daarom is het belangrijk de kans op ernstig verlopende infecties in te schatten. Gelet op leeftijdsspecifieke infecties, het klinisch beloop en de complicaties ervan, en gelet op de geassocieerde klinische tekenen van discom- fort of van alarmtekenen moet bij jonge kinderen anders op koorts gereageerd worden dan bij andere leeftijdsgroepen.

Doelstelling van deze studie is een wetenschappelijk gefundeerde aanbeveling formuleren opdat herkenning en opvolging van klinische (alarm)tekenen kunnen leiden tot correcte en vooral wetenschappelijk onderbouwde opvolging en aanpak van koorts in de preventieve gezinsondersteuning en kinderopvang.

Methode

Via grondige literatuurstudie wordt 